\title{
Valorization of Cereal By-Products from the Milling Industry as a Source of Nutrients and Bioactive Compounds to Boost Resource-Use Efficiency
}

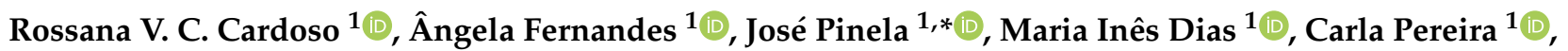 \\ Tânia C. S. P. Pires ${ }^{1}\left(\mathbb{D}\right.$, Márcio Carocho ${ }^{1} \mathbb{D}$, Esteban Fernández Vasallo ${ }^{2}$, Isabel C. F. R. Ferreira ${ }^{1}$ (D) \\ and Lillian Barros $1, *$ (D) \\ 1 Centro de Investigação de Montanha (CIMO), Instituto Politécnico de Bragança, Campus de Santa Apolónia, \\ 5300-253 Bragança, Portugal; rossana@ipb.pt (R.V.C.C.); afeitor@ipb.pt (Â.F.); maria.ines@ipb.pt (M.I.D.); \\ carlap@ipb.pt (C.P.); tania.pires@ipb.pt (T.C.S.P.P.); mcarocho@ipb.pt (M.C.); iferreira@ipb.pt (I.C.F.R.F.) \\ 2 Molendum Ingredient, Calle de la Milana S/N, Coreses, 49530 Zamora, Spain; e.fernandez@molendum.com \\ * Correspondence: jpinela@ipb.pt (J.P.); lillian@ipb.pt (L.B.)
}

Citation: Cardoso, R.V.C.; Fernandes, Â.; Pinela, J.; Dias, M.I.; Pereira, C.; Pires, T.C.S.P.; Carocho, M.; Vasallo, E.F.; Ferreira, I.C.F.R.; Barros, L

Valorization of Cereal By-Products from the Milling Industry as a Source of Nutrients and Bioactive Compounds to Boost Resource-Use Efficiency. Agronomy 2021, 11, 972. https://doi.org/10.3390/ agronomy11050972

Academic Editor: Eduardo Aguilera

Received: 16 April 2021

Accepted: 11 May 2021

Published: 13 May 2021

Publisher's Note: MDPI stays neutral with regard to jurisdictional claims in published maps and institutional affiliations.

Copyright: (c) 2021 by the authors. Licensee MDPI, Basel, Switzerland. This article is an open access article distributed under the terms and conditions of the Creative Commons Attribution (CC BY) license (https:/ / creativecommons.org/licenses/by/ $4.0 /$ )

\begin{abstract}
Cereal by-products (wheat germ, maize bran-germ mixture, rye bran, and wheat bran) from the flour milling industry were characterized for their nutritional value and chemical composition, as well as for antioxidant and antibacterial activities. Carbohydrates (including sucrose) were the major nutritional constituents (56.35-78.12 g/100 g dw), followed by proteins (11.2-30.0 g/100 g dw). The higher energy value $(432.3 \mathrm{kcal} / 100 \mathrm{~g} \mathrm{dw})$ was presented by the wheat germ. This by-product also presented the highest citric acid content $(0.857 \mathrm{~g} / 100 \mathrm{~g} \mathrm{dw})$, the most abundant organic acid detected. Unsaturated fatty acids predominated in all samples given the high content of linoleic (53.9-57.1\%) and oleic (13.4-29.0\%) acids. Wheat germ had the highest levels of tocopherols (22.8 mg/100 g dw) and phenolic compounds (5.7 $\mathrm{mg} / \mathrm{g}$ extract, with a high apigenin- $C$-pentoside- $C$-hexoside content). In turn, while the wheat bran extract was particularly effective in inhibiting the formation of thiobarbituric acid reactive substances (TBARS), the rye bran extract was the only sample capable of protecting erythrocytes from oxidative hemolysis. Regarding antibacterial properties, in general, the lowest minimum inhibitory concentrations were observed against methicillin-resistant Staphylococcus aureus. These results highlight the characterized by-products as sustainable ingredients for the development of novel bakery and functional food products and contribute to a better bioresource-use efficiency and circularity.
\end{abstract}

Keywords: cereal bran/germ; nutritional quality; chemical composition; antioxidant activity; antimicrobial activity; bioresource-use efficiency

\section{Introduction}

Cereal grains are rich in phytochemicals and nutrients, such as phenolic acids, flavonoids, carbohydrates, dietary fibers, proteins, and tocopherols, among other constituents, which have a vital role in preventing cardiovascular and digestive system diseases, overweight and obesity, inflammation, type 2 diabetes, and some types of cancer [1]. Some studies have shown that consumers are increasingly aware of the relationship between diet and disease, and there is a trend towards a gradual decrease in the consumption of animalderived protein and a demand for plant-based diets, which have well-known physical and environmental health benefits [2,3].

The food industry has focused on the production of functional foods based on different types of cereals, due to the growing consumer's demand for healthier foods [4,5]. For this purpose, both cereals and their constituents offer unlimited potential and are an excellent raw material for the production of functional foods and functional ingredients, in particular for the design of novel food products based on cereals or their by-products [6]. Cereals 
include rice, wheat, rye, maize, barley, sorghum, millet, and oats, among others, and their global production is very extensive as they are the basis of many human diets worldwide. Therefore, the sector is taking into account the sustainability and the efficient use of the by-products generated by the crops or during cereal processing [7]. These result in valuable by-products during milling, such as bran, germ, coat, husk, or endosperm, which could be a good source of potentially marketable ingredients and bioactive compounds [6]. The milling industries commonly release these by-products in the field or direct them to animal feed, bioethanol production, cosmetics, meat substitutes, and nutraceutical/pharmaceutical products, among other applications [8].

During the milling operation, the endosperm is broken down into fine particles (flour), while the germ and bran are removed. The germ is a good source of vitamins (B and tocopherol), minerals, proteins, dietary fiber, carbohydrates, fatty acids, flavonoids, glutathione, and sterols [8-11]. The bran contains fibers and antioxidants, heteroxylans, cellulose, proteins, starch, phenolic acids, lipids, and minerals [12,13].

With the growing world population and given the limited resources our planet can provide, it is essential to produce enough food to meet the growing demands and needs of the human population and also to ensure food security. However, with restricted arable land, the agri-food industry by-products should become recycled within the food chain and, thus, be valorized as a sustainable source of food and food ingredients [6,14], also promoting the circular economy. Therefore, this study was performed to provide a detailed nutritional and chemical characterization of cereal by-products, namely wheat, maize, and rye bran and/or germ, currently produced in large quantities by food ingredients industrial groups, but which have low or no commercial value. Antioxidant and antibacterial activities were also evaluated after preparation of hydroethanolic extracts with these cereal by-products. Overall, it was intended to demonstrate that these milling by-products can have value-added potential in the food market as a low-cost material for the development of nutrient-rich ingredients and bioactive compounds.

\section{Materials and Methods}

\subsection{Samples and Samples Preparation}

Cereal by-products (wheat germ, maize bran-germ mixture, rye bran, and wheat bran) were kindly supplied by the "Dacsa Group", a food ingredients industrial group from Almàssera-Valencia, Spain, in March 2018. The dry samples were reduced to a fine powder, packaged in sealed plastic bags, and stored at $-20^{\circ} \mathrm{C}$ until further analysis.

\subsection{Standards and Reagents}

High-performance liquid chromatography (HPLC)-grade acetonitrile (99.9\%), n-hexane $(95 \%)$, and ethyl acetate $(99.8 \%)$ were purchased from Fisher Scientific (Lisbon, Portugal). The fatty acid methyl ester standard mixture 47885-U, formic acid, 6-hydroxy-2,5,7,8tetramethylchroman-2-carboxylic acid (Trolox), L-ascorbic acid, 2,2'-Azobis(2-amidinopropane) dihydrochloride (AAPH), and the tocopherol $(\alpha, \beta, \gamma$, and $\delta$ isoforms), free sugar, and organic acid standards were obtained from Sigma-Aldrich (St. Louis, MO, USA). Phenolic compounds standards were acquired from Extrasynthèse (Genay, France). Thiamine, casamino acids, malt extract, and agar were obtained from Panreac AppliChem (Barcelona, Spain). PDA and PDB mediums were acquired from Oxoid microbiology products (Hampshire, UK). $p$-Iodonitrotetrazolium chloride (INT) was purchased from Panreac Applichem (Barcelona, Spain), Tryptic Soy Broth (TSB), and Mueller- Hinton (MH) from Biolab ${ }^{\circledR}$ (Budapest, Hungary). All other reagents and solvents were of analytical grade and obtained from common sources. Water was treated in a Milli-Q water purification system (TGI Pure Water Systems, Greenville, SC, USA).

\subsection{Determination of Nutrients and Energy Value}

Fat, protein, and ash contents were determined by AOAC procedures [15]. The crude fat content was determined by Soxhlet extraction of the samples with petroleum ether 
(AOAC 920.85). The ash (total mineral) content was determined by samples incineration at $550 \pm 15^{\circ} \mathrm{C}$ (AOAC 923.03). The crude protein content was analyzed using an automatic distillation and titration unit (Pro-Nitro-A model, JP Selecta, Barcelona) by the macroKjeldahl method (AOAC 978.04) ( $\mathrm{N} \times$ correction factor, namely 5.70 for wheat germ, 6.25 for maize bran/germ mixture, 5.83 for rye bran, and 6.31 for wheat bran) [16]. The results were expressed in g per $100 \mathrm{~g}$ of dry weight (dw).

Total carbohydrates were calculated by difference according to Equation (1).

$$
\text { Carbohydrates }(\mathrm{g} / 100 \mathrm{~g} \mathrm{dw})=100-(\mathrm{g} \text { protein }+\mathrm{g} \text { fat }+\mathrm{g} \text { ash })
$$

The energy was calculated according to the Regulation (EU) No 1169/2011 of the European Parliament and of the Council [17], as shown in Equation (2).

$$
\text { Energy }(\mathrm{kcal} / 100 \mathrm{~g} \mathrm{dw})=4 \times(\mathrm{g} \text { protein }+\mathrm{g} \text { carbohydrates })+9 \times(\mathrm{g} \text { fat })
$$

\subsection{Evaluation of Chemical Constituents}

\subsubsection{Organic Acids}

The organic acids profile was analyzed by ultra-fast liquid chromatography (UFLC; Shimadzu 20A series, Kyoto, Japan) following a procedure previously described and optimized by Pereira et al. [18]. Briefly, the samples $(1 \mathrm{~g})$ were stirred with $25 \mathrm{~mL}$ of meta-phosphoric acid for $45 \mathrm{~min}$ and filtered, first through Whatman No. 4 filter paper and then through $0.2 \mu \mathrm{m}$ nylon filters. Chromatographic separation was achieved in reverse phase on a C18 column $(5 \mu \mathrm{m}$ particle size, $250 \times 4.6 \mathrm{~mm}$; Phenomenex, Torrance, CA, USA). Detection was performed in a photo-diode array detector (PDA), at 215 and $245 \mathrm{~nm}$ (for ascorbic acid). The detected compounds were identified and quantified by chromatographic comparison of the peak area with calibration curves obtained from commercial standards of oxalic $\left(\mathrm{y}=1 \times 10^{7} \mathrm{x}+231,891 ; r^{2}=0.9999\right.$; limit of detection $(\mathrm{LOD})=6.3 \mu \mathrm{g} / \mathrm{mL}$; limit of quantification $(\mathrm{LOQ})=20.8 \mu \mathrm{g} / \mathrm{mL}$ ), malic $\left(\mathrm{y}=950,041 \mathrm{x}+6255.6 ; r^{2}=0.9999 ; \mathrm{LOD}=15.9 \mu \mathrm{g} / \mathrm{mL} ; \mathrm{LOQ}=52.9 \mu \mathrm{g} / \mathrm{mL}\right)$, ascorbic $\left(\mathrm{y}=4 \times 10^{7} \mathrm{x}+1 \times 10^{6} ; r^{2}=0.9909 ; \mathrm{LOD}=0.29 \mu \mathrm{g} / \mathrm{mL} ; \mathrm{LOQ}=0.96 \mu \mathrm{g} / \mathrm{mL}\right)$, shikimic $\left(7 \times 10^{7} x+175,156 ; \quad r^{2}=0.9999 ; \quad\right.$ LOD $\left.=10.2 \mu \mathrm{g} / \mathrm{mL} ; \quad \mathrm{LOQ}=56.5 \mu \mathrm{g} / \mathrm{mL}\right), \quad$ citric $\left(\mathrm{y}=1 \times 10^{6} \mathrm{x}-10,277 ; r^{2}=0.9997 ; \mathrm{LOD}=4.4 \mu \mathrm{g} / \mathrm{mL} ; \mathrm{LOQ}=14.5 \mu \mathrm{g} / \mathrm{mL}\right)$, and fumaric $\left(\mathrm{y}=185,062 \mathrm{x}+117,588 ; r^{2}=1 ; \mathrm{LOD}=42.5 \mu \mathrm{g} / \mathrm{mL} ; \mathrm{LOQ}=141.7 \mu \mathrm{g} / \mathrm{mL}\right)$ acids. The results were expressed in $\mathrm{g}$ per $100 \mathrm{~g} \mathrm{dw}$.

\subsubsection{Free Sugars}

Soluble sugars were analyzed in a HPLC system coupled to a refraction index (RI) detector as previously described by Spréa et al. [19]. Briefly, the samples (1 g) were spiked with melezitose (internal standard, $5 \mathrm{mg} / \mathrm{mL}$ ) and extracted with $80 \%$ ethanol at $80{ }^{\circ} \mathrm{C}$. The mixture was centrifuged and the supernatant was concentrated and defatted with ethyl ether. After concentration at $40{ }^{\circ} \mathrm{C}$, the residues were dissolved in $5 \mathrm{~mL}$ of water and filtered through $0.2-\mu \mathrm{m}$ nylon filters. Identification was achieved by comparing the sample retention times with those of the authentic standards, while quantification was based on the internal standard method, with calibration curves constructed with commercial standards of fructose $\left(\mathrm{y}=1.04 \mathrm{x} ; r^{2}=0.999 ; \mathrm{LOD}=0.05 \mathrm{mg} / \mathrm{mL} ; \mathrm{LOQ}=0.18 \mathrm{mg} / \mathrm{mL}\right)$, glucose $\left(\mathrm{y}=0.935 \mathrm{x} ; r^{2}=0.999 ; \mathrm{LOD}=0.08 \mathrm{mg} / \mathrm{mL} ; \mathrm{LOQ}=0.25 \mathrm{mg} / \mathrm{mL}\right)$, sucrose $(\mathrm{y}=0.977 \mathrm{x}$; $\left.r^{2}=0.999 ; \mathrm{LOD}=0.06 \mathrm{mg} / \mathrm{mL} ; \mathrm{LOQ}=0.21 \mathrm{mg} / \mathrm{mL}\right)$, trehalose $\left(\mathrm{y}=0.991 \mathrm{x} ; r^{2}=0.999 ;\right.$ $\mathrm{LOD}=0.07 \mathrm{mg} / \mathrm{mL} ; \mathrm{LOQ}=0.24 \mathrm{mg} / \mathrm{mL})$, and raffinose $\left(\mathrm{y}=0.891 \mathrm{x}, r^{2}=0.9999\right.$; $\mathrm{LOD}=0.09 \mathrm{mg} / \mathrm{mL} ; \mathrm{LOQ}=0.30 \mathrm{mg} / \mathrm{mL}$ ). The results were expressed in $\mathrm{g}$ per $100 \mathrm{~g} \mathrm{dw}$.

\subsubsection{Fatty Acids}

After transesterification of the lipid fraction obtained by Soxhlet extraction [19], the fatty acid methyl ester (FAME) mixture was analyzed by gas-liquid chromatography with flame ionization detection, using a YOUNG IN Chromass 6500 GC System apparatus equipped with a split/splitless injector, a flame ionization detector (FID), and a Zebron- 
Fame column. Identification were made by chromatographic comparison of the retention times of the sample FAME peaks with those of the standard 47885-U (Sigma-Aldrich, St. Louis, MO, USA). The results were recorded and processed using Clarity DataApex 4.0 Software (Prague, Czech Republic) and expressed in relative percentage of each fatty acid.

\subsubsection{Tocopherols}

Tocopherols were analyzed accordingly to a procedure described by Spréa et al. [19], using the HPLC system coupled to a fluorescence detector (FP-2020; Jasco), programmed for excitation at $290 \mathrm{~nm}$ and emission at $330 \mathrm{~nm}$. Briefly, the samples (500 mg) were spiked with a BHT solution $(10 \mathrm{mg} / \mathrm{mL})$ and tocol (internal standard, $50 \mu \mathrm{g} / \mathrm{mL})$, and homogenized first with $4 \mathrm{~mL}$ of methanol and then with $4 \mathrm{~mL}$ of hexane. Then, $2 \mathrm{~mL}$ of saturated $\mathrm{NaCl}$ aqueous solution were added, the mixture was homogenized, centrifuged, and the upper layer was collected. The extraction was repeated twice with hexane. The extracts were dried under a nitrogen stream, redissolved in $2 \mathrm{~mL}$ of $n$-hexane, dehydrated, and filtered through $0.22-\mu \mathrm{m}$ syringe filters. Chromatographic separation was performed in normal phase on a Polyamide II column (5 $\mu \mathrm{m}$ particle size, $250 \times 4.6 \mathrm{~mm}$; YMC, Kyoto, Japan). Identification was made by chromatographic comparison with authentic standards and quantification was based on the fluorescence signal response of each standard, using the internal standard (tocol) method and calibration curves constructed from commercial standards of $\alpha$-tocopherol ( $\left.\mathrm{y}=1.295 \mathrm{x} ; r^{2}=0.991 ; \mathrm{LOD}=18.06 \mathrm{ng} / \mathrm{mL} ; \mathrm{LOQ}=60.20 \mathrm{ng} / \mathrm{mL}\right), \beta$ tocopherol $\left(\mathrm{y}=0.396 \mathrm{x} ; r^{2}=0.992 ; \mathrm{LOD}=25.82 \mathrm{ng} / \mathrm{mL} ; \mathrm{LOQ}=86.07 \mathrm{ng} / \mathrm{mL}\right), \gamma$-tocopherol $\left(\mathrm{y}=0.567 \mathrm{x} ; r^{2}=0.991 ; \mathrm{LOD}=14.79 \mathrm{ng} / \mathrm{mL} ; \mathrm{LOQ}=49.32 \mathrm{ng} / \mathrm{mL}\right)$, and $\delta$-tocopherol $\left(\mathrm{y}=0.678 \mathrm{x} ; r^{2}=0.992 ; \mathrm{LOD}=20.09 \mathrm{ng} / \mathrm{mL} ; \mathrm{LOQ}=66.95 \mathrm{ng} / \mathrm{mL}\right)$. The results were expressed in $\mathrm{mg}$ per $100 \mathrm{~g} \mathrm{dw}$.

\subsection{Evaluation of Phenolic Compounds and Bioactivities}

\subsubsection{Extracts Preparation}

The dry material was used to prepare hydroethanolic extracts as described by Mariotti et al. [16]. The samples $(2.5 \mathrm{~g})$ were mixed with $30 \mathrm{~mL}$ of ethanol/water $(80: 20, v / v)$ and stirred for $1 \mathrm{~h}$ at $25^{\circ} \mathrm{C}$. The mixtures were then filtered through Whatman No. 4 filter paper and the residues were re-extracted with $30 \mathrm{~mL}$ of the same hydroalcoholic mixture. The extracts were first concentrated under reduced pressure (rotary evaporator Büchi R-210, Flawil, Switzerland) at $40{ }^{\circ} \mathrm{C}$ and then lyophilized (FreeZone 4.5, Labconco, Kansas City, MO, USA).

\subsubsection{Phenolic Compounds}

Phenolic compounds were analyzed in the hydroethanolic extracts, which were redissolved in ethanol/water $(80: 20, v / v)$ to a final concentration of $10 \mathrm{mg} / \mathrm{mL}$ and filtered through $0.22-\mu \mathrm{m}$ disposable filter disks. The analysis was performed in an HPLC system (Dionex Ultimate 3000 UPLC, Thermo Scientific, San Jose, CA, USA) coupled with a diodearray detector (DAD, using 280 and $370 \mathrm{~nm}$ as preferred wavelengths) and a Linear Ion Trap (LTQ XL) mass spectrometer (MS, Thermo Finnigan, San Jose, CA, USA) equipped with an electrospray ionization (ESI) source. Chromatographic separation was performed on a Waters Spherisorb S3 ODS-2 column (3 $\mu \mathrm{m}, 4.6 \mathrm{~mm} \times 150 \mathrm{~mm}$; Waters, Milford, MA, USA). The operating conditions were previously described by the Bessada et al. [20], as well as the identification and quantification procedures. The results were given as mg per g of extract.

\subsubsection{Antioxidant Activity}

The thiobarbituric acid reactive substances (TBARS) formation inhibition and oxidative hemolysis inhibition (OxHLIA) assays were performed in vitro. Trolox was used as a positive control in both assays. For TBARS, the lyophilized extracts were re-dissolved in ethanol/water (80:20, $v / v)$ and subjected to successive dilutions from 10 to $0.019 \mathrm{mg} / \mathrm{mL}$. The lipid peroxidation inhibition was evaluated by the decrease in TBARS formation, using 
porcine (Sus scrofa) brain cell homogenates. The color intensity of the malondialdehydethiobarbituric acid adduct in the mixtures was monitored spectrophotometrically at $532 \mathrm{~nm}$. The inhibition ratio $(\%)$ was calculated using the following formula: $[(\mathrm{A}-\mathrm{B}) / \mathrm{A}] \times 100$, where A and B correspond to the absorbance of control and sample solution, respectively [16]. The results were expressed in $\mathrm{IC}_{50}$ values $(\mathrm{mg} / \mathrm{mL})$, which translate the extract concentration providing $50 \%$ of antioxidant activity. For OxHLIA, the anti-hemolytic activity was assessed as described by Silva de Sá et al. [21]. Briefly, an erythrocyte solution (2.8\%, $v / v ; 200 \mu \mathrm{L}$ ) was mixed with $400 \mu \mathrm{L}$ of either: (i) extract solution $(0.106-3.4 \mathrm{mg} / \mathrm{mL}$ in PBS); (ii) PBS (control); (iii) water (for complete hemolysis); or (iv) trolox (7.81-250 $\mu \mathrm{g} / \mathrm{mL}$ ). After pre-incubation at $37^{\circ} \mathrm{C}$ for $10 \mathrm{~min}$ with shaking, $200 \mu \mathrm{L}$ of AAPH (160 mM in PBS) were added and the optical density was measured at $690 \mathrm{~nm}$ every $~ 10 \mathrm{~min}$ in a microplate reader (Bio-Tek Instruments, ELX800) until complete hemolysis. The results were expressed as $\mathrm{IC}_{50}$ values $(\mathrm{mg} / \mathrm{mL})$, translating the extract concentration able to promote a $\Delta t$ hemolysis delay of 60 and $120 \mathrm{~min}$.

\subsubsection{Antibacterial Activity}

The antibacterial activity was evaluated by the broth microdilution method coupled to the rapid $p$-iodonitrotetrazolium chloride (INT) colorimetric assay [22]. The tested microorganisms were clinical isolates from patients hospitalized in various departments of the Local Health Unit of Bragança and Hospital Center of Trás-os-Montes and AltoDouro Vila Real, Northeast of Portugal, and included three Gram-positive (Enterococcus faecalis, Listeria monocytogenes, and methicillin resistant Staphylococcus aureus) and five Gram-negative (Escherichia coli, Klebsiella pneumoniae, Morganella morganii, Proteus mirabilis, and Pseudomonas aeruginosa) bacteria. The microorganisms' identification and susceptibility (Table S1) tests were performed as described in Supplementary Material. The minimum inhibitory concentration (MIC) was determined by the colorimetric microbial viability based on the reduction of the INT colorant $(0.2 \mathrm{mg} / \mathrm{mL})$. The minimum bactericidal concentration $(\mathrm{MBC})$ was evaluated by plating the wells content without coloration in the MIC assay. Antibiotics were used as positive controls, namely ampicillin $(20 \mathrm{mg} / \mathrm{mL})$ and imipenem $(1 \mathrm{mg} / \mathrm{mL})$ for Gram-negative bacteria, and vancomycin $(1 \mathrm{mg} / \mathrm{mL})$ and ampicillin $(20 \mathrm{mg} / \mathrm{mL})$ for Gram-positive bacteria.

\subsection{Statistical Analysis}

All analyses were performed in triplicate and the results were presented as mean \pm standard deviation (SD) (except for antibacterial activity). Since the number of significant figures of the mean value is conditioned by the $\mathrm{SD}$, the $\mathrm{SD}$ was rounded to one significant figure, which indicated in which decimal place the uncertain digit of the mean value was. The results were analyzed by a one-way analysis of variance (ANOVA) followed by a Tukey's HSD test, with $\alpha=0.05$. A Student's $t$-test was applied when only two samples were compared. SPSS v. 23.0 was used for all statistical analysis.

\section{Results and Discussion}

Cereal by-products represent an unexploited source of nutrients and bioactive compounds and could serve as low-cost materials for the development of novel functional and fortifying ingredients for foods and functional foods, as well as for non-food products. Therefore, the macronutrient and micronutrient composition of wheat, rye, and maize bran and/or germ supplied by the milling industry are herein described, as well as their composition in phenolic compounds and in vitro antioxidant and antibacterial activities.

\subsection{Compositional Features of the Cereal By-Products}

The results in Table 1 show the proximate composition of the different cereal byproducts, including fat, protein, ash, and carbohydrates content and energy value. Carbohydrates were the most prevalent constituents, ranging from $56.35 \mathrm{~g} / 100 \mathrm{~g}$ dw in wheat germ to $78.12 \mathrm{~g} / 100 \mathrm{~g} \mathrm{dw}$ in maize bran-germ mixture. The results are slightly higher 
than the $46.07 \mathrm{~g} / 100 \mathrm{~g}$ dw previously reported by Mahmoud et al. [23] for wheat germ sample from Egypt. Proteins were the second most abundant nutrients and the contents differed significantly between cereal by-products. Interestingly, the samples with the lowest carbohydrate content had the highest protein level. As shown in Table 1, $30.0 \mathrm{~g} / 100 \mathrm{~g} \mathrm{dw}$ were quantified in wheat germ, whose $100-\mathrm{g}$ portions can provide 53.6 and $65.2 \%$ of the recommended dietary allowances of protein for adult male and female individual, respectively [24]. The two by-products with germ, namely wheat germ and the maize bran-germ mixture, presented higher quantities of crude fat (9.64 and $8.08 \mathrm{~g} / 100 \mathrm{~g} \mathrm{dw}$, respectively) than the bran samples. Navarro et al. [25] and Mahmoud et al. [23] reported a higher fat content in maize bran-germ $(10.74 \mathrm{~g} / 100 \mathrm{~g} \mathrm{dw})$ and wheat germ $(10.29 \mathrm{~g} / 100 \mathrm{~g} \mathrm{dw})$ samples from Brazil and Egypt, respectively. Fats are important nutritional constituents of cereal by-products, being a source of essential fatty acids and energy, and play an important role in their quality [26]. Overall, in terms of energetic contribution, wheat germ presented the highest value $(432.3 \mathrm{kcal} / 100 \mathrm{~g} \mathrm{dw})$ in accordance with the higher fat and protein contents, followed by the maize bran-germ mixture (429.8 kcal/100 $\mathrm{g} \mathrm{dw})$ and wheat bran $(412.4 \mathrm{kcal} / 100 \mathrm{~g} \mathrm{dw})$. The rye bran samples showed the lowest energy value, reaching only $405.4 \mathrm{kcal} / 100 \mathrm{~g}$ dw. Mahmoud et al. [23] reported similar energy values for wheat germ (430.3 kcal/100 $\mathrm{g} \mathrm{dw}$ ), while the National Food Institute [27] presents lower values for wheat germ (379 kcal/100 g), wheat bran (291 kcal/100 g), and common rye flour (322 kcal/100 g). The INRAE-CIRAD-AFZ [28] composition tables present high energy values for maize germ $(690 \mathrm{kcal} / 100 \mathrm{~g})$ and bran $(457 \mathrm{kcal} / 100 \mathrm{~g})$. However, to the best of the authors' knowledge, this is the first study describing the energy value of the maize bran-germ mixture and rye bran.

Table 1. Proximate composition and energy value of the cereal by-products.

\begin{tabular}{lcccc}
\hline & Wheat Germ & Maize Bran-Germ & Rye Bran & Wheat Bran \\
\hline Fat $(\mathrm{g} / 100 \mathrm{~g} \mathrm{dw})$ & $9.64 \pm 0.01^{\mathrm{a}}$ & $8.08 \pm 0.01^{\mathrm{b}}$ & $3.9 \pm 0.1^{\mathrm{d}}$ & $5.05 \pm 0.02^{\mathrm{c}}$ \\
Proteins $(\mathrm{g} / 100 \mathrm{~g} \mathrm{dw})$ & $30.0 \pm 0.1^{\mathrm{a}}$ & $11.2 \pm 0.2^{\mathrm{d}}$ & $15.3 \pm 0.1^{\mathrm{c}}$ & $16.4 \pm 0.1^{\mathrm{b}}$ \\
Ash $(\mathrm{g} / 100 \mathrm{~g} \mathrm{dw})$ & $3.97 \pm 0.05^{\mathrm{a}}$ & $2.66 \pm 0.04^{\mathrm{d}}$ & $3.54 \pm 0.04^{\mathrm{b}}$ & $3.12^{\mathrm{a}} \pm 0.04^{\mathrm{c}}$ \\
Carbohydrates $(\mathrm{g} / 100 \mathrm{~g} \mathrm{dw})$ & $56.35 \pm 0.02^{\mathrm{d}}$ & $78.12 \pm 0.04^{\mathrm{a}}$ & $77.2 \pm 0.1^{\mathrm{b}}$ & $75.42 \pm 0.01^{\mathrm{c}}$ \\
Energy (kcal/100 g dw) & $432.3 \pm 0.1^{\mathrm{a}}$ & $429 \pm 0.2^{\mathrm{b}}$ & $405.4 \pm 011^{\mathrm{d}}$ & $412.8^{\mathrm{a}} \pm 0.1^{\mathrm{c}}$ \\
\hline
\end{tabular}

In each line, different letters indicate significant differences $(p<0.05)$ between samples. The number of significant figures of each mean value was conditioned by the standard deviation, which was rounded to one significant figure.

Table 2 shows the free sugars and organic acids detected in the cereal by-products, namely five sugars and six organic acids characterized by HPLC-RI and UFLC-PDA, respectively. Regarding free sugars, sucrose was the most abundant in all cereal byproducts, reaching $10.4 \mathrm{~g} / 100 \mathrm{~g} \mathrm{dw}$ in wheat germ, $3.84 \mathrm{~g} / 100 \mathrm{~g} \mathrm{dw}$ in the maize brangerm mixture, and approximately $2.9 \mathrm{~g} / 100 \mathrm{~g} \mathrm{dw}$ in the bran samples. These results are in agreement with those of Rizzello et al. [29], who also reported sucrose as the main soluble sugar in wheat germ $(7.2 \mathrm{~g} / 100 \mathrm{~g} \mathrm{dw})$. Table 2 also shows that the free sugar profile of the different samples is different, as some of these water-soluble molecules were not detected in some of the studied cereal by-products. Trehalose and fructose were detected only in wheat germ $(0.25 \mathrm{~g} / 100 \mathrm{~g} \mathrm{dw})$ and maize bran-germ mixture (0.15 g/100 g dw), respectively, while rye bran did not contain glucose. Overall, the total amount of free sugars ranged from $3.51 \mathrm{~g} / 100 \mathrm{~g}$ dw to $15.2 \mathrm{~g} / 100 \mathrm{~g}$ dw in wheat germ, this last sample with a considerable difference towards the other cereal by-products. The National Food Institute [27] reported a similar value for a wheat germ sample from Denmark, namely $15.7 \mathrm{~g} / 100 \mathrm{~g} \mathrm{dw}$ of total free sugars. It is also interesting to note that free sugars correspond to $27 \%$ of the carbohydrate fraction of wheat germ and less than $6 \%$ in the remaining samples. 
Table 2. Composition in sugars and organic acids of the cereal by-products.

\begin{tabular}{|c|c|c|c|c|}
\hline & Wheat Germ & $\begin{array}{c}\text { Maize } \\
\text { Bran-Germ }\end{array}$ & Rye Bran & Wheat Bran \\
\hline \multicolumn{5}{|c|}{ Free sugars (g/100 g dw) } \\
\hline Fructose & nd & $0.15 \pm 0.02$ & nd & nd \\
\hline Glucose & $0.18 \pm 0.01^{\mathrm{c}}$ & $0.16 \pm 0.01^{b}$ & nd & $0.14 \pm 0.01^{\mathrm{a}}$ \\
\hline Sucrose & $10.4 \pm 0.1^{\mathrm{a}}$ & $3.84 \pm 0.01^{b}$ & $2.92 \pm 0.03^{c}$ & $2.9 \pm 0.1^{c}$ \\
\hline Trehalose & $0.25 \pm 0.01$ & nd & nd & nd \\
\hline Raffinose & $4.65 \pm 0.03^{\mathrm{a}}$ & $0.4 \pm 0.1^{\mathrm{d}}$ & $0.59 \pm 0.01^{\mathrm{c}}$ & $1.69 \pm 0.01^{b}$ \\
\hline Total of free sugars & $15.2 \pm 0.1^{\mathrm{a}}$ & $4.4 \pm 0.1^{\mathrm{c}}$ & $3.51 \pm 0.02^{d}$ & $4.7 \pm 0.1^{\mathrm{b}}$ \\
\hline \multicolumn{5}{|c|}{ Organic acid (g/100 g dw) } \\
\hline Oxalic acid & $0.090 \pm 0.001^{b}$ & $0.105 \pm 0.001^{\mathrm{a}}$ & $0.0471 \pm 0.0001^{\mathrm{d}}$ & $0.0593 \pm 0.0001^{c}$ \\
\hline Malic acid & nd & nd & $\operatorname{tr}$ & $\operatorname{tr}$ \\
\hline Ascorbic acid & $\operatorname{tr}$ & $\operatorname{tr}$ & nd & nd \\
\hline Shikimic acid & nd & nd & nd & $\operatorname{tr}$ \\
\hline Citric acid & $0.857 \pm 0.002^{\mathrm{a}}$ & $0.204 \pm 0.001^{\mathrm{d}}$ & $0.424 \pm 0.001^{\mathrm{c}}$ & $0.539 \pm 0.001^{b}$ \\
\hline Fumaric acid & $\operatorname{tr}$ & $\operatorname{tr}$ & $\operatorname{tr}$ & $\operatorname{tr}$ \\
\hline Total of organic acids & $0.946 \pm 0.002^{\mathrm{a}}$ & $0.309 \pm 0.001^{\mathrm{d}}$ & $0.471 \pm 0.001^{\mathrm{c}}$ & $0.598 \pm 0.001^{\mathrm{b}}$ \\
\hline
\end{tabular}

In each line, different letters indicate significant differences $(p<0.05)$ between samples. The number of significant figures of each mean value was conditioned by the standard deviation, which was rounded to one significant figure. nd —not detected; tr-traces (below LOQ).

Regarding organic acids, malic, ascorbic, shikimic, and fumaric acids were detected in trace amounts and just in some samples (Table 2). Citric acid was the main compound identified in the cereal by-products, and its levels contribute greatly to the total amounts of organic acids recorded in wheat germ $(0.946 \mathrm{~g} / 100 \mathrm{~g} \mathrm{dw})$, followed by wheat bran (0.598 $\mathrm{g} / 100 \mathrm{~g} \mathrm{dw})$, rye bran $(0.471 \mathrm{~g} / 100 \mathrm{~g} \mathrm{dw})$, and maize bran-germ mixture with the lowest levels $(0.309 \mathrm{~g} / \mathrm{g} 100 \mathrm{~g} \mathrm{dw})$. Oxalic acid was also detected in all samples, especially in the maize bran-germ mixture $(0.105 \mathrm{~g} / 100 \mathrm{~g} \mathrm{dw})$. To the best of the authors knowledge, this is the first report describing the organic acids composition of these byproducts. However, wheat is recognized as a complete cereal because it has much higher soluble sugars and organic acids than other cereals, regardless of the cereal part under analysis (bran or germ). Sugars and organic acids are important quality indicators that can be related to preservation and storage conditions [30,31].

Table 3 shows the lipophilic compounds detected in the cereal by-products, namely fatty acids and tocopherols. The GC-FID analysis allowed the detection of 13 fatty acids, whose contents are presented in relative percentage. Linoleic acid (C18:2n6c) was the most abundant fatty acid, with levels up to 53\% in all samples. Similar C18:2n6c contents (55.1 and 54.4\%) were reported by Mahmoud et al. [23] for a wheat germ oil sample from Egypt and by Abdelghany et al. [32] for soybean seed accessions collected in China, respectively. This essential fatty acid is precursor of eicosanoids, which take part in many biological processes, and required for normal human health. Oleic acid (C18:1n9c) ranked second and prevailed in the maize bran-germ mixture (29\%). This omega- 9 fatty acid was also previously reported as the second most abundant in soybean in a slightly lower relative percentage (24.6\%) [32]. Regarding saturated fatty acids (SFA), palmitic acid (C16:0) was the major contributor and prevailed in wheat bran and germ samples (with approximately $18 \%)$, while stearic acid (C18:0) predominated in the maize bran-germ mixture $(2.96 \%)$. In turn, the higher amounts of monounsaturated fatty acids (MUFA) were quantified in the maize bran-germ mixture (29.2\%). In general, polyunsaturated fatty acids (PUFA) predominated in all samples, with levels ranging from 55.9 to $65.4 \%$. The fatty acid profiles observed in the characterized cereal by-products are in agreement with previous reports [33-36]. Fatty acids are good food quality indicators, since lipid peroxidation affects the overall quality and odor of cereals when stored for a long period [30,37]. 
Table 3. Composition in fatty acids and tocopherols of the cereal by-products.

\begin{tabular}{|c|c|c|c|c|}
\hline & Wheat Germ & $\begin{array}{c}\text { Maize } \\
\text { Bran-Germ }\end{array}$ & Rye Bran & Wheat Bran \\
\hline \multicolumn{5}{|c|}{ Fatty acids (relative \%) } \\
\hline $\mathrm{C} 14: 0$ & $0.12 \pm 0.01^{b}$ & nd & $0.14 \pm 0.01^{\mathrm{a}}$ & $0.126 \pm 0.001^{b}$ \\
\hline C15:0 & $0.073 \pm 0.003^{c}$ & nd & $0.15 \pm 0.01^{\mathrm{a}}$ & $0.104 \pm 0.001^{b}$ \\
\hline C16:0 & $18.02 \pm 0.02^{\mathrm{a}}$ & $10.6 \pm 0.3^{c}$ & $15.59 \pm 0.04^{b}$ & $18.3 \pm 0.2^{\mathrm{a}}$ \\
\hline C16:1 & $0.17 \pm 0.02^{c}$ & $0.101 \pm 0.004^{\mathrm{d}}$ & $0.27 \pm 0.02^{\mathrm{a}}$ & $0.20 \pm 0.01^{b}$ \\
\hline C18:0 & $0.86 \pm 0.01^{\mathrm{c}}$ & $2.955 \pm 0.001^{\mathrm{a}}$ & $1.3 \pm 0.1^{b}$ & $1.32 \pm 0.01^{b}$ \\
\hline $\mathrm{C} 18: \ln 9 \mathrm{c}$ & $13.4 \pm 0.1^{\mathrm{d}}$ & $29.0 \pm 0.1^{\mathrm{a}}$ & $17.31 \pm 0.04^{b}$ & $16.07 \pm 0.04^{c}$ \\
\hline $\mathrm{C} 18: 2 \mathrm{n} 6 \mathrm{c}$ & $57.1 \pm 0.1^{\mathrm{a}}$ & $54.8 \pm 0.2^{\mathrm{c}}$ & $53.9 \pm 0.1^{\mathrm{d}}$ & $56.3 \pm 0.2^{b}$ \\
\hline C18:3n3 & $8.0 \pm 0.1^{b}$ & $1.04 \pm 0.01^{\mathrm{d}}$ & $8.6 \pm 0.1^{\mathrm{a}}$ & $5.17 \pm 0.05^{c}$ \\
\hline C20:0 & $0.205 \pm 0.001^{\mathrm{c}}$ & $0.48 \pm 0.01^{\mathrm{a}}$ & nd & $0.24 \pm 0.01^{b}$ \\
\hline C20:1 & $1.35 \pm 0.03^{b}$ & $0.168 \pm 0.005^{\mathrm{d}}$ & $1.456 \pm 0.003^{\mathrm{a}}$ & $1.0 \pm 0.1^{\mathrm{c}}$ \\
\hline C22:0 & $0.25 \pm 0.02^{\mathrm{c}}$ & $0.36 \pm 0.03^{b}$ & $0.42 \pm 0.01^{\mathrm{a}}$ & $0.41 \pm 0.01^{\mathrm{a}}$ \\
\hline C20:5n3 & $0.30 \pm 0.02^{\mathrm{c}}$ & nd & $0.47 \pm 0.01^{\mathrm{a}}$ & $0.40 \pm 0.02^{b}$ \\
\hline C24:0 & $0.20 \pm 0.01^{\mathrm{d}}$ & $0.46 \pm 0.01^{b}$ & $0.49 \pm 0.03^{\mathrm{a}}$ & $0.29 \pm 0.01^{c}$ \\
\hline SFA & $19.73 \pm 0.02^{b}$ & $14.9 \pm 0.3^{\mathrm{d}}$ & $18.1 \pm 0.1^{\mathrm{c}}$ & $20.8 \pm 0.2^{\mathrm{a}}$ \\
\hline MUFA & $14.9 \pm 0.1^{\mathrm{d}}$ & $29.2 \pm 0.1^{\mathrm{a}}$ & $19.03 \pm 0.02^{b}$ & $17.3 \pm 0.1^{\mathrm{c}}$ \\
\hline PUFA & $65.4 \pm 0.1^{\mathrm{a}}$ & $55.9 \pm 0.2^{d}$ & $62.9 \pm 0.1^{b}$ & $61.9 \pm 0.3^{c}$ \\
\hline \multicolumn{5}{|c|}{ Tocopherols (mg/100 g dw) } \\
\hline$\alpha$-Tocopherol & $13.46 \pm 0.01^{\mathrm{a}}$ & $3.38 \pm 0.02^{d}$ & $4.1 \pm 0.1^{\mathrm{c}}$ & $5.23 \pm 0.04^{b}$ \\
\hline$\beta$-Tocopherol & $9.27 \pm 0.04^{\mathrm{a}}$ & $0.12 \pm 0.03^{d}$ & $1.27 \pm 0.01^{\mathrm{c}}$ & $2.99 \pm 0.01^{b}$ \\
\hline$\gamma$-Tocopherol & nd & $1.61 \pm 0.03^{\mathrm{a}}$ & nd & $0.140 \pm 0.001^{b}$ \\
\hline$\delta$-Tocopherol & $0.046 \pm 0.001$ & nd & nd & nd \\
\hline Total of tocopherols & $22.8 \pm 0.1^{\mathrm{a}}$ & $5.10 \pm 0.02^{\mathrm{d}}$ & $5.4 \pm 0.1^{\mathrm{c}}$ & $8.35 \pm 0.04^{b}$ \\
\hline
\end{tabular}

In each line, different letters indicate significant differences $(p<0.05)$ between samples. The number of significant figures of each mean value was conditioned by the standard deviation, which was rounded to one significant figure. SFA—saturated fatty acids; MUFAmonounsaturated fatty acids; PUFA— polyunsaturated fatty acids; nd—not detected.

The results of the tocopherols composition are also shown in Table 3. $\alpha$-Tocopherol was found in all cereal by-products and as the predominant isoform, especially in wheat germ $(13.46 \mathrm{mg} / 100 \mathrm{~g} \mathrm{dw})$, where it was possible to detected $\delta$-tocopherol. The study of Górnaś et al. [38] reports lower $\alpha$-tocopherol values for wheat and rye bran $(1.9$ and $1.4 \mathrm{mg} / 100 \mathrm{~g}$ $\mathrm{dw}$, respectively) than those achieved in the present study. In turn, higher levels were obtained by Ansolin et al. [39] in wheat germ oil ( $28.5 \mathrm{mg} / 100 \mathrm{~g})$ and by Navarro et al. [25] in maize bran-germ oil ( $13 \mathrm{mg} / 100 \mathrm{~g} \mathrm{dw})$. Wheat bran and germ samples stand out with the highest amounts of $\beta$-tocopherol (2.99 and $9.27 \mathrm{mg} / 100 \mathrm{~g} \mathrm{dw}$, respectively). Only two samples contained $\gamma$-tocopherol, namely the maize bran-germ mixture and wheat bran (1.61 and $0.14 \mathrm{mg} / 100 \mathrm{~g} \mathrm{dw}$, respectively). The tocopherol profiles herein reported are in agreement with those previously reported $[9,25,38]$. Overall, wheat by-products showed the highest concentration of tocopherols, with $22.8 \mathrm{mg} / 100 \mathrm{~g}$ dw quantified in the germ and $8.35 \pm 0.04 \mathrm{mg} / 100 \mathrm{~g} \mathrm{dw}$ in the bran. Based on the $\alpha$-tocopherol values in Table 3 and the recommended dietary allowances for vitamin $\mathrm{E}$ of $15 \mathrm{mg} /$ day for healthy adults [24], it could be concluded that a $100 \mathrm{~g}$ portion of wheat germ contributes $61.8 \%$ to the intake of this liposoluble vitamin.

\subsection{Phenolic Composition of the Cereal By-Products}

Cereal by-products are important sources of phytochemicals such as phenolic compounds, which have gained major attention since they exhibit a wide range of biological activities, including antioxidant and antimicrobial effects $[40,41]$. The chromatographic information (retention time, wavelengths of maximum absorption in the visible region $\left(\lambda_{\max }\right)$, and mass spectral data) used in the tentative identification of the phenolic compounds detected in the hydroethanolic extracts prepared with the cereals by-products are shown in Table 4 . Eleven phenolic compounds were tentatively identified in the extracts, including 4 
phenolic acids ( $p$-coumaroyl, caffeic, and chlorogenic acid derivatives), 6 flavonoids (luteolin and apigenin $C$-glycosylated derivatives) and one unknown compound that was found in maize bran-germ and rye bran samples. Regarding phenolic acids, peak 1 presented a pseudomolecular ion $[\mathrm{M}-\mathrm{H}]^{-}$at $m / z 487$ and a unique $\mathrm{MS}^{2}$ fragment at $m / z 163$ (loss of two hexosyl moieties), coupled to a characteristic UV spectrum of p-coumaric acid at $301 \mathrm{~nm}$, the peak was tentatively identified as $p$-coumaric acid dihexoside. Peaks 2 and 3 were tentatively identified as caffeic acid hexoside, presenting a pseudomolecular ion $[\mathrm{M}-\mathrm{H}]^{-}$at $m / z 341$ and $\mathrm{MS}^{2}$ fragments at $m / z 179,161$, and 135, that correspond to the break of the caffeic acid unit and the loss of one hexosyl moiety $(341-179=162 \mathrm{u})$. Finally, peak 9, with $[\mathrm{M}-\mathrm{H}]^{-}$at $m / z 515$ and $\lambda_{\max } 311 \mathrm{~nm}$ (characteristic of chlorogenic acid derivatives), was tentatively identified as 3,5-O-dicaffeoylquinic acid using the hierarchical fragmentation pattern previously reported by Clifford et al. [42,43].

Table 4. Phenolic compounds tentatively identified in the hydroethanolic extracts of the cereal by-products. It is presented the retention time $(\mathrm{Rt})$, wavelengths of maximum absorption in the visible region $\left(\lambda_{\max }\right)$, and mass spectral data.

\begin{tabular}{|c|c|c|c|c|c|}
\hline Peak & $\begin{array}{c}\text { Rt } \\
(\mathrm{min})\end{array}$ & $\begin{array}{l}\lambda_{\max } \\
(\mathrm{nm})\end{array}$ & $\begin{array}{c}{[\mathrm{M}-\mathrm{H}]^{-}} \\
(\mathrm{m} / \mathrm{z})\end{array}$ & $\operatorname{MS}^{2}(m / z)$ & Tentative Identification \\
\hline 1 & 4.7 & 301 & 487 & $162(100)$ & $p$-Coumaric acid dihexoside \\
\hline 2 & 4.8 & 311 & 341 & 179(100), 161(15), 132(5) & Caffeic acid hexoside \\
\hline 3 & 5.43 & 311 & 341 & $179(100), 161(15), 132(5)$ & Caffeic acid hexoside \\
\hline 4 & 11.45 & 345 & 579 & $459(35), 429(10), 357(5), 327(10), 309(5)$ & Luteolin-O-pentoside-C-hexoside \\
\hline 5 & 12.11 & 287 & 385 & $267(100), 249(20)$ & Unknown compound \\
\hline 6 & 12.86 & 336 & 563 & 545(43), 473(100), 443(7), 383(31), 353(28), 311(5) & Apigenin- $C$-pentoside- $C$-hexoside \\
\hline 7 & 13.21 & 326 & 563 & $545(20), 473(92), 443(100), 383(28), 353(25), 311(5)$ & Apigenin- $C$-hexoside- $C$-pentoside \\
\hline 8 & 14.21 & 336 & 563 & $545(32), 473(100), 443(98), 383(38), 353(31), 311(5)$ & Apigenin- $C$-pentoside- $C$-hexoside \\
\hline 9 & 17.11 & 324 & 515 & 353(60), 191(100), 179(30), 173(5), 161(5), 135(5) & 3,5-O-Dicaffeoylquinic acid \\
\hline 10 & 19.65 & 331 & 769 & 563(11), 545(81), 425(100), 335(31) & $\begin{array}{l}\text { Sinapic acid ester of } \\
\text { apigenin-C-diglycoside }\end{array}$ \\
\hline 11 & 20.53 & 331 & 769 & $563(10), 545(89), 425(100), 335(12)$ & $\begin{array}{l}\text { Sinapic acid ester of } \\
\text { apigenin-C-diglycoside }\end{array}$ \\
\hline
\end{tabular}

The flavonoids group represented the majority of the compounds identified in the cereal by-products, being apigenin derivatives the ones with higher expression in all samples (expect in maize bran). Peaks 6, 7, and 8 all presented the same pseudomolecular ion $[\mathrm{M}-\mathrm{H}]^{-}$at $m / z 563$, and characteristics $\mathrm{MS}^{2}$ fragment at $m / z 473(90 \mathrm{u}), 383(90 \mathrm{u}), 353$ $(30 \mathrm{u})$, that correspond to the loss of units in multiples of 30 , leading to the identification of $\mathrm{C}$-glycosylated derivatives. The differentiation between the three peaks, take into account the abundance of $100 \%$ in $\mathrm{MS}^{2}$ fragment at $m / z 473$ in peaks 6 and 8 , and the $\mathrm{MS}^{2}$ fragment at $m / z 443$ in peak 7 , which lead to the tentative identification of apigenin- $C$-pentoside$C$-hexoside (peaks 6 and 8) and apigenin- $C$-hexoside- $C$-pentoside (peak 7) [44]. Peaks 10 and 11 presented a pseudomolecular ion $[\mathrm{M}-\mathrm{H}]^{-}$at $\mathrm{m} / z 769$ and an $\mathrm{MS}^{2}$ fragmentation pattern coherent with that previously described by Hirawan and Beta [45] in whole-wheat Spaghetti, being both tentatively identified as sinapic acid esters of apigenin- $C$-diglycoside. Finally, the last flavonoid found was peak 4 tentatively identified as luteolin-O-pentoside$C$-hexoside ([M-H $]^{-}$at $\left.m / z 579\right)$, using the chromatographic profile previously described by Roriz et al. [46].

As presented in Table 5, the flavonoids group represents the majority (in content) of the compounds found in all samples (except for maize bran), more specifically, $81 \%$ $(4.7 \mathrm{mg} / \mathrm{g}$ extract) in wheat germ and $77 \%$ (3.4 mg/g extract) in wheat bran of the total phenolic compounds. These concentrations are mainly due to the presence of apigenin$C$-pentoside-C-hexoside, with $2.95 \mathrm{mg} / \mathrm{g}$ of extract in the wheat germ and $2.09 \mathrm{mg} / \mathrm{g}$ of extract in wheat bran. In maize bran and rye bran, phenolic acids were detected in higher concentrations, $0.046 \mathrm{mg} / \mathrm{g}$ extract in maize bran (peak 2 corresponded to the only phenolic compound found in this sample) and $0.93 \mathrm{mg} / \mathrm{g}$ extract in rye bran (mainly due to the 
presence of $p$-coumaric acid dihexoside, in agreement with previous reports found in the literature [47-49].

Table 5. Phenolic compounds content in the hydroethanolic extracts of the cereal by-products.

\begin{tabular}{|c|c|c|c|c|c|}
\hline \multirow[t]{2}{*}{ Peak } & \multirow[t]{2}{*}{ Tentative Identification } & \multicolumn{4}{|c|}{ Content (mg/g Extract) } \\
\hline & & Wheat Germ & $\begin{array}{c}\text { Maize } \\
\text { Bran-Germ }\end{array}$ & Rye Bran & Wheat Bran \\
\hline 1 & $p$-Coumaric acid dihexoside & nd & nd & $0.57 \pm 0.02$ & nd \\
\hline 2 & Caffeic acid hexoside & $0.088 \pm 0.001^{b}$ & $0.046 \pm 0.001^{\mathrm{c}}$ & nd & $0.115 \pm 0.006^{\mathrm{a}}$ \\
\hline 3 & Caffeic acid hexoside & nd & nd & nd & nd \\
\hline 4 & Luteolin- $\mathrm{O}$-pentoside- $\mathrm{C}$-hexoside & $0.121 \pm 0.004$ * & nd & nd & $0.084 \pm 0.001$ \\
\hline 5 & Unknown compound & nd & $\mathrm{nq}$ & $\mathrm{nq}$ & nd \\
\hline 6 & Apigenin- $C$-pentoside- $C$-hexoside & $0.602 \pm 0.01 *$ & nd & nd & $0.39 \pm 0.01$ \\
\hline 7 & Apigenin- $C$-hexoside- $C$-pentoside & $1.004 \pm 0.058^{*}$ & nd & nd & $0.80 \pm 0.05$ \\
\hline 8 & Apigenin- $C$-pentoside- $C$-hexoside & $2.9 \pm 0.1^{\mathrm{a}}$ & nd & $0.067 \pm 0.002^{c}$ & $2.1 \pm 0.1^{b}$ \\
\hline 9 & 3,5-O-Dicaffeoylquinic acid & $0.34 \pm 0.01^{\mathrm{a}}$ & nd & $0.293 \pm 0.001^{b}$ & $0.35 \pm 0.01^{\mathrm{a}}$ \\
\hline 10 & $\begin{array}{l}\text { Sinapic acid ester of } \\
\text { apigenin- } C \text {-diglycoside }\end{array}$ & $0.16 \pm 0.01$ * & nd & nd & $0.140 \pm 0.001$ \\
\hline \multirow[t]{4}{*}{11} & $\begin{array}{l}\text { Sinapic acid ester of } \\
\text { apigenin- } C \text {-diglycoside }\end{array}$ & $0.470 \pm 0.001^{\mathrm{a}}$ & nd & $0.057 \pm 0.001^{c}$ & $0.413 \pm 0.007^{b}$ \\
\hline & $\Sigma$ Phenolic acids & $1.066 \pm 0.002^{\mathrm{a}}$ & $0.046 \pm 0.001^{d}$ & $0.93 \pm 0.02^{c}$ & $1.017 \pm 0.001^{b}$ \\
\hline & $\Sigma$ Flavonoids & $4.7 \pm 0.1^{\mathrm{a}}$ & nd & $0.067 \pm 0.002^{c}$ & $3.4 \pm 0.1^{\mathrm{b}}$ \\
\hline & $\Sigma$ Phenolic compounds & $5.7 \pm 0.1^{a}$ & $0.046 \pm 0.001^{\mathrm{d}}$ & $0.418 \pm 0.003^{c}$ & $4.3 \pm 0.1^{b}$ \\
\hline
\end{tabular}

Calibration curves used in quantification: apigenin-6-C-glucoside $\left(\mathrm{y}=107025 \mathrm{x}+61531, r^{2}=0.9989, \mathrm{LOD}=0.19 \mu \mathrm{g} / \mathrm{mL} ; \mathrm{LOQ}=0.63 \mu \mathrm{g} / \mathrm{mL}\right.$; peak 6, 7, and 8); caffeic acid ( $\mathrm{y}=388345 \mathrm{x}+406369, r^{2}=0.9939, \mathrm{LOD}=0.78 \mu \mathrm{g} / \mathrm{mL}$, and $\mathrm{LOQ}=1.97 \mu \mathrm{g} / \mathrm{mL}$; peaks 2 and 3); chlorogenic acid $\left(\mathrm{y}=168823 \mathrm{x}-161172, r^{2}=0.9999, \mathrm{LOD}=0.20 \mu \mathrm{g} / \mathrm{mL}\right.$, and LOQ $=0.68 \mu \mathrm{g} / \mathrm{mL}$; peak 9); luteolin-6-C-glucoside $(\mathrm{y}=4087.1 \mathrm{x}+72589$, $r^{2}=0.9988, \mathrm{LOD}=0.20 \mu \mathrm{g} / \mathrm{mL}$, and $\mathrm{LOQ}=0.45 \mu \mathrm{g} / \mathrm{mL}$; peak 4$) ; p$-coumaric acid $\left(\mathrm{y}=301950 \mathrm{x}+6966.7, r^{2}=0.9999, \mathrm{LOD}=0.68 \mu \mathrm{g} / \mathrm{mL}\right.$, and $\mathrm{LOQ}=1.61 \mu \mathrm{g} / \mathrm{mL}$; peak 1$)$; sinapic acid $\left(\mathrm{y}=197337 \mathrm{x}+30036, r^{2}=0.9997, \mathrm{LOD}=0.17 \mu \mathrm{g} / \mathrm{mL}\right.$, and $\mathrm{LOQ}=1.22 \mu \mathrm{g} / \mathrm{mL} ; \mathrm{peaks} 10 \mathrm{and}$ 11). Statistically significant differences $(p<0.05)$ between more than two samples were assessed by a one-way ANOVA, using Tukey's significant difference (HSD), and are indicated by different letters; significant differences $(p<0.001)$ between two samples * were assessed by a Student's $t$-test. The number of significant figures of each mean value was conditioned by the standard deviation, which was rounded to one significant figure. nd-not detected; nq—not quantified.

Wheat germ and bran were the samples presenting the highest concentration of phenolic compounds (5.7 and $4.4 \mathrm{mg} / \mathrm{g}$ extract, respectively), and also a higher concentration of total phenolic acids (1.066 and $1.017 \mathrm{mg} / \mathrm{g}$ extract, respectively). The phenolic compounds of wheat were previously studied by different authors, with different phenolic acids and results obtained. Zou et al. [50] reported ferulic acid as the major compound found in wheat germ $(250 \mu \mathrm{g} / \mathrm{g}$ of extract $)$ and $554 \mu \mathrm{g} / \mathrm{g}$ extract of total phenolic acids. Vaher [51], in bran spring wheat, also reported ferulic acid was the main one $(268.9 \mu \mathrm{g} / \mathrm{g} \mathrm{dw})$ and the amount of total phenolic acids was $569 \mu \mathrm{g} / \mathrm{g}$ dw. López-Perea et al. [52] reported caffeic acid as the major compound $(0.86 \mu \mathrm{g} / \mathrm{g} \mathrm{dw})$ and the total of phenolic compound was $100 \mu \mathrm{g} / \mathrm{g} \mathrm{dw}$ in wheat bran. Skrajda-Brdak et al. [49] reported ferulic acid $(222.1 \mu \mathrm{g} / \mathrm{g}$ $\mathrm{dw})$ as the main compound and the total phenolic acids content was $273.2 \mu \mathrm{g} / \mathrm{g} \mathrm{dw}$ for common wheat.

\subsection{Bioactivity of the Cereal By-Products}

Whole cereal grains have been described as having great bioactive properties due to their fractions, bran and germ, that comprise health-promoting bioactive compounds [41]. Therefore, the antioxidant activity of the cereal by-product hydroethanolic extracts was evaluated in vitro by the thiobarbituric acid reactive substances (TBARS) formation inhibition, using porcine brain tissue homogenates, and the oxidative hemolysis inhibition assay (OxHLIA), using sheep erythrocytes. The results are presented in Table 6 and were expressed in $\mathrm{IC}_{50}$ values, translating the extract concentration providing $50 \%$ of antioxidant activity in the TBARS assay or the concentration able to protect $50 \%$ of the erythrocyte population in OxHLIA. The cereal by-product with the best TBARS formation inhibition 
capacity was the wheat bran (with the lowest $\mathrm{IC}_{50}$ value of $0.26 \mathrm{mg} / \mathrm{mL}$ ), followed by the maize bran-germ mixture and rye bran. The lowest activity was shown by the wheat germ extract, not agreeing, therefore, with the highest content of phenolic compounds quantified in this sample (Table 5), but coinciding with the highest levels of citric acids (Table 2) and tocopherols (Table 3). For OxHLIA, only rye bran presented capacity to protect the erythrocyte membrane form the free radicals generated in the system by the thermal decomposition of AAPH. The other extracts did not delay hemolysis compared to the used negative control (PBS). It should be noted that the lower $\mathrm{IC}_{50}$ values of trolox are due to the fact that this positive control is a pure antioxidant compound, while the natural extracts tested are complex mixtures of different constituents, some of which have no activity. The antioxidant activity of the studied cereals has been demonstrated by previous studies, but must of them used chemical methods, such as reducing power, 2,2diphenyl-1-picrylhydrazyl (DPPH) radical scavenging activity, and Folin-Ciocalteu assays, among others [53-55]. However, cell-based assays have been described as more suitable to measure the antioxidant activity of natural products than chemical methods [56]. It is also worth noting that, according to some studies, cereal phenolic acids display antioxidant properties in vitro due to the presence of an aromatic phenolic ring [41].

Table 6. Antioxidant activity $\left(\mathrm{IC}_{50}\right.$ values, $\mathrm{mg} / \mathrm{mL}$ ) of the cereal by-product hydroethanolic extracts.

\begin{tabular}{|c|c|c|c|c|c|}
\hline & Wheat Germ & $\begin{array}{c}\text { Maize } \\
\text { Bran-Germ }\end{array}$ & Rye Bran & Wheat Bran & Trolox \\
\hline TBARS & $4.8 \pm 0.1^{\mathrm{a}}$ & $0.62 \pm 0.01^{\mathrm{c}}$ & $0.98 \pm 0.01^{b}$ & $0.26 \pm 0.01^{\mathrm{d}}$ & $0.023 \pm 0.001$ \\
\hline OxHLIA, $\Delta t 60 \mathrm{~min}$ & na & na & $0.58 \pm 0.02$ & na & $0.020 \pm 0.001$ \\
\hline OxHLIA, $\Delta t 120 \mathrm{~min}$ & na & na & $1.02 \pm 0.04$ * & na & $0.041 \pm 0.001$ \\
\hline
\end{tabular}

For TBARS, statistically significant differences $(p<0.05)$ between samples were assessed by a one-way ANOVA, using Tukey's significant difference (HSD), and are indicated by different letters; for OxHLIA, significant differences $(p<0.001)$ between the two samples * were assessed by a Student's $t$-test. The number of significant figures of each mean value was conditioned by the standard deviation, which was rounded to one significant figure. na-no activity.

The antibacterial activity of the cereal by-products was also tested against Grampositive and Gram-negative bacteria and the results are presented in Table 7 as minimum inhibitory and bactericidal concentrations (MIC and MBC, respectively). In general, the extracts were not very effective against the selected foodborne microorganisms. The best results were achieved against methicillin-resistant Staphylococcus aureus with the maize bran-germ moisture extract (MIC of $2.5 \mathrm{mg} / \mathrm{mL}$ ) and rye bran and wheat bran extracts (MIC of $5 \mathrm{mg} / \mathrm{mL}$ ). MBC values above $20 \mathrm{mg} / \mathrm{mL}$ were obtained in all cases. Among the tested microorganisms, the Gram-positive bacteria appear to be more susceptible to the extracts than the Gram-negative bacteria. The positive controls ampicillin, imipenem, and vancomycin yielded much lower MIC and MBC values, as expected for commercial antibiotics. Despite the low efficacy of the tested extracts, isolated compounds such as phenolic acids can display remarkable antimicrobial effects [41], which highlights their potential for application as preservatives in food and food-packing materials, among others. Regarding previous studies, Călinoiu and Vodnar [57] reported better results for heat processed wheat bran, with an MIC of $1.875 \mathrm{mg} / \mathrm{mL}$ against Enterococcus faecalis. In turn, a moderate antibacterial effect toward Pseudomonas aeruginosa was achieved with heat processed wheat bran and fresh wheat bran extracts, with MIC values of $3.75 \mathrm{mg} / \mathrm{mL}$ and $7.5 \mathrm{mg} / \mathrm{mL}$, respectively. The same authors attributed moderate antibacterial activity to heat processed wheat bran against Escherichia coli (MIC of $3.75 \mathrm{mg} / \mathrm{mL}$ ) and Salmonella typhimurium (MIC of $7.5 \mathrm{mg} / \mathrm{mL}$ ). 
Table 7. Antibacterial activity $(\mathrm{mg} / \mathrm{mL})$ of the cereal by-product hydroethanolic extracts.

\begin{tabular}{|c|c|c|c|c|c|c|c|c|c|c|c|c|c|c|}
\hline & \multicolumn{2}{|c|}{$\begin{array}{l}\text { Wheat } \\
\text { Germ }\end{array}$} & \multicolumn{2}{|c|}{$\begin{array}{c}\text { Maize } \\
\text { Bran-Germ }\end{array}$} & \multicolumn{2}{|c|}{ Rye Bran } & \multicolumn{2}{|c|}{ Wheat Bran } & \multicolumn{2}{|c|}{ Ampicillin } & \multicolumn{2}{|c|}{ Imipenem } & \multicolumn{2}{|c|}{ Vancomycin } \\
\hline & $\mathrm{MIC}$ & $\mathrm{MBC}$ & $\mathrm{MIC}$ & $\mathrm{MBC}$ & $\mathrm{MIC}$ & $\mathrm{MBC}$ & $\mathrm{MIC}$ & MBC & MIC & MBC & MIC & MBC & MIC & MBC \\
\hline \multicolumn{15}{|c|}{ Gram-negative bacteria } \\
\hline Escherichia coli & 10 & $>20$ & 10 & $>20$ & 20 & $>20$ & 20 & $>20$ & $<0.15$ & $<0.15$ & $<0.0078$ & $<0.0078$ & nt & nt \\
\hline Klebsiella pneumoniae & $>20$ & $>20$ & $>20$ & $>20$ & $>20$ & $>20$ & $>20$ & $>20$ & 10 & 20 & $<0.0078$ & $<0.0078$ & nt & nt \\
\hline Morganella morganii & 20 & $>20$ & 20 & $>20$ & 20 & $>20$ & 20 & $>20$ & 20 & $>20$ & $<0.0078$ & $<0.0078$ & nt & nt \\
\hline Proteus mirabilis & $>20$ & $>20$ & $>20$ & $>20$ & $>20$ & $>20$ & $>20$ & $>20$ & $<015$ & $<0.15$ & $<0.0078$ & $<0.0078$ & nt & nt \\
\hline Pseudomonas aeruginosa & $>20$ & $>20$ & $>20$ & $>20$ & $>20$ & $>20$ & $>20$ & $>20$ & $>20$ & $>20$ & 0.5 & 1 & nt & nt \\
\hline \multicolumn{15}{|c|}{ Gram-positive bacteria } \\
\hline Enterococcus faecalis & 10 & $>20$ & 20 & $>20$ & 20 & $>20$ & 20 & $>20$ & $<0.15$ & $<0.15$ & nt & nt & $<0.0078$ & $<0.0078$ \\
\hline Listeria monocytogenes & 10 & $>20$ & 20 & $>20$ & 20 & $>20$ & 10 & $>20$ & $<0.15$ & $<0.15$ & $<0.0078$ & $<0.0078$ & nt & nt \\
\hline MRSA & 10 & $>20$ & 2.5 & $>20$ & 5 & $>20$ & 5 & $>20$ & $<0.15$ & $<0.15$ & nt & nt & 0.25 & 0.5 \\
\hline
\end{tabular}

MRSA-Methicillin-resistant Staphylococcus aureus; MIC—minimum inhibitory concentration; MBC-minimal bactericidal concentration; nt-not tested.

\section{Conclusions}

This study contributes to the valorization of cereal by-products generated worldwide by the flour milling industry. The findings herein described are valid arguments to support the use of the industry's cereal germ and bran by-products as underexploited alternative sources of nutrients and bioactive compounds with potential health benefits for consumers. Among the studied cereal by-products, wheat germ has emerged as an interesting source of protein and vitamin E, given the high contribution to the recommended dietary allowances. Wheat germ, maize bran-germ mixture, rye bran, and wheat bran could be directed to human nutrition as a sustainable way to promote the development of novel and functional foods, the bioresource-use efficiency, and the circular bioeconomy in this so important food sector. The results can also be useful to complete food and/or feed composition tables.

Supplementary Materials: The following are available online at https: / www.mdpi.com/article / 10.3390/agronomy11050972/s1, Table S1: Resistance profile of the tested Gram-positive and Gramnegative bacteria to different antibiotics. Minimum inhibitory concentration (MIC) in $\mu \mathrm{g} / \mathrm{mL}$.

Author Contributions: Conceptualization, E.F.V. and L.B.; methodology, R.V.C.C., Â.F., J.P., M.I.D., and T.C.S.P.P.; investigation, R.V.C.C., Â.F., J.P., and M.I.D.; data curation, Â.F., J.P., M.I.D., and T.C.S.P.P.; writing-original draft preparation, R.V.C.C. and M.C.; writing-review and editing, Â.F., J.P., M.I.D., C.P., L.B., and I.C.F.R.F.; visualization and supervision, L.B. and I.C.F.R.F.; project administration, L.B.; funding acquisition, L.B. All authors have read and agreed to the published version of the manuscript.

Funding: The authors are grateful to the Foundation for Science and Technology (FCT, Portugal) for financial support by national funds FCT/MCTES to CIMO (UIDB/00690/2020) and national funding by FCT, P.I., through the institutional scientific employment program-contract for L. Barros, A. Fernandes, M.I. Dias, and C. Pereira and through the individual scientific employment program-contract for J. Pinela (CEECIND/01011/2018) and M. Carocho (CEECIND/00831/2018). To FEDER-Interreg España-Portugal program for financial support through the project TRANSCoLAB 0612_TRANS_CO_LAB_2_P.

Institutional Review Board Statement: Not applicable.

Informed Consent Statement: Not applicable.

Conflicts of Interest: The authors declare no conflict of interest.

\section{References}

1. Monnet, A.F.; Laleg, K.; Michon, C.; Micard, V. Legume enriched cereal products: A generic approach derived from material science to predict their structuring by the process and their final properties. Trends Food Sci. Technol. 2019, 86, 131-143. [CrossRef]

2. Kim, H.; Caulfield, L.E.; Garcia-Larsen, V.; Steffen, L.M.; Coresh, J.; Rebholz, C.M. Plant-based diets are associated with a lower risk of incident cardiovascular disease, cardiovascular disease mortality, and all-cause mortality in a general population of middle-aged adults. J. Am. Heart Assoc. 2019, 8, 1-13. [CrossRef] [PubMed] 
3. Lynch, H.; Johnston, C.; Wharton, C. Plant-based diets: Considerations for environmental impact, protein quality, and exercise performance. Nutrients 2018, 10, 1841. [CrossRef]

4. Bigliardi, B.; Galati, F. Innovation trends in the food industry: The case of functional foods. Trends Food Sci. Technol. 2013, 31, 118-129. [CrossRef]

5. Klopčič, M.; Slokan, P.; Erjavec, K. Consumer preference for nutrition and health claims: A multi-methodological approach. Food Qual. Prefer. 2020, 82, 1-10. [CrossRef]

6. Saini, A.; Panwar, D.; Panesar, P.; Bera, M. Bioactive compounds from cereal and pulse processing byproducts and their potential health benefits. Austin J. Nutr. Metab. 2019, 6, 1-7.

7. Tapia-Hernández, J.A.; Del-Toro-Sánchez, C.L.; Cinco-Moroyoqui, F.J.; Juárez-Onofre, J.E.; Ruiz-Cruz, S.; Carvajal-Millan, E.; López-Ahumada, G.A.; Castro-Enriquez, D.D.; Barreras-Urbina, C.G.; Rodríguez-Felix, F. Prolamins from cereal by-products: Classification, extraction, characterization and its applications in micro- and nanofabrication. Trends Food Sci. Technol. 2019, 90, 111-132. [CrossRef]

8. Tsadik, Y.Y.G.; Emire, S.A. Development of value added products from byproducts of Ethiopian wheat milling industries. J. Food Process. Technol. 2015, 6, 1-8.

9. Ghafoor, K.; Özcan, M.M.; AL-Juhaımı, F.; Babıker, E.E.; Sarker, Z.I.; Ahmed, I.A.M.; Ahmed, M.A. Nutritional composition, extraction, and utilization of wheat germ oil: A review. Eur. J. Lipid Sci. Technol. 2017, 119, 1-9. [CrossRef]

10. Tolouie, H.; Mohammadifar, M.A.; Ghomi, H.; Yaghoubi, A.S.; Hashemi, M. The impact of atmospheric cold plasma treatment on inactivation of lipase and lipoxygenase of wheat germs. Innov. Food Sci. Emerg. Technol. 2018, 47, 346-352. [CrossRef]

11. Yun, L.; Wang, S.; Wu, T.; Li, Q.; Zhang, M. Structural characterization of a novel glycoprotein in wheat germ and its physicochemical properties. Int. J. Biol. Macromol. 2018, 117, 1058-1065. [CrossRef] [PubMed]

12. Anderson, C.; Simsek, S. Mechanical profiles and topographical properties of films made from alkaline extracted arabinoxylans from wheat bran, maize bran, or dried distillers grain. Food Hydrocoll. 2019, 86, 78-86. [CrossRef]

13. Holguín-Acuña, A.L.; Carvajal-Millán, E.; Santana-Rodríguez, V.; Rascón-Chu, A.; Márquez-Escalante, J.A.; de León-Renova, N.E.P.; Gastelum-Franco, G. Maize bran/oat flour extruded breakfast cereal: A novel source of complex polysaccharides and an antioxidant. Food Chem. 2008, 111, 654-657. [CrossRef]

14. Arte, E.; Huang, X.; Nordlund, E.; Katina, K. Biochemical characterization and technofunctional properties of bioprocessed wheat bran protein isolates. Food Chem. 2019, 289, 103-111. [CrossRef]

15. AOAC International. Official Methods of Analysis of AOAC International, 20th ed.; Latimer, G.W., Ed.; AOAC International: Gaithersburg, MD, USA, 2016.

16. Mariotti, F.; Tomé, D.; Mirand, P.P. Converting nitrogen into protein-Beyond 6.25 and Jones' factors. Crit. Rev. Food Sci. Nutr. 2008, 48, 177-184. [CrossRef]

17. European Union. Regulation (EU) No 1169/2011 of the European Parliament and of the Council of 25 October 2011; European Union: Brussels, Belgium, 2011.

18. Pereira, C.; Barros, L.; Carvalho, A.M.; Ferreira, I.C.F.R. Use of UFLC-PDA for the Analysis of Organic Acids in Thirty-Five Species of Food and Medicinal Plants. Food Anal. Methods 2013, 6, 1337-1344. [CrossRef]

19. Spréa, R.M.; Fernandes, Â.; Calhelha, R.C.; Pereira, C.; Pires, T.C.S.P.; Alves, M.J.; Canan, C.; Barros, L.; Amaral, J.S.; Ferreira, I.C.F.R. Chemical and bioactive characterization of the aromatic plant: Levisticum officinale W.D.J. Koch: A comprehensive study. Food Funct. 2020, 11, 1292-1303. [CrossRef]

20. Bessada, S.M.F.; Barreira, J.C.M.; Barros, L.; Ferreira, I.C.F.R.; Oliveira, M.B.P.P. Phenolic profile and antioxidant activity of Coleostephus myconis (L.) Rchb.f.: An underexploited and highly disseminated species. Ind. Crop. Prod. 2016, 89, 45-51. [CrossRef]

21. De Sá, I.S.; Peron, A.P.; Leimann, F.V.; Bressan, G.N.; Krum, B.N.; Fachinetto, R.; Pinela, J.; Calhelha, R.C.; Barreiro, M.F.; Ferreira, I.C.F.R.; et al. In vitro and in vivo evaluation of enzymatic and antioxidant activity, cytotoxicity and genotoxicity of curcumin-loaded solid dispersions. Food Chem. Toxicol. 2019, 125, 29-37. [CrossRef] [PubMed]

22. Alves, M.J.; Ferreira, I.C.F.R.; Lourenço, I.; Costa, E.; Martins, A.; Pintado, M. Wild mushroom extracts as inhibitors of bacterial biofilm formation. Pathogens 2014, 3, 667-679. [CrossRef]

23. Mahmoud, A.A.; Mohdaly, A.A.A.; Elneairy, N.A.A. Wheat germ: An overview on nutritional value, antioxidant potential and antibacterial characteristics. Food Nutr. Sci. 2015, 6, 265-277. [CrossRef]

24. Otten, J.J.; Hellwig, J.P.; Meyers, L.D. Dietary Reference Intakes: The Essential Guide to Nutrient Requirements; Otten, J.J., Hellwig, J.P., Meyers, L.D., Eds.; The National Academies Press: Washington, WA, USA, 2006.

25. Navarro, S.L.B.; Capellini, M.C.; Aracava, K.K.; Rodrigues, C.E.C. Corn germ-bran oils extracted with alcoholic solvents: Extraction yield, oil composition and evaluation of protein solubility of defatted meal. Food Bioprod. Process. 2016, 100, 185-194. [CrossRef]

26. Cardoso, R.V.C.; Fernandes, Â.; Heleno, S.A.; Rodrigues, P.; Gonzaléz-paramás, A.M.; Barros, L.; Ferreira, I.C.F.R. Physicochemical characterization and microbiology of wheat and rye flours. Food Chem. 2019, 280, 123-129. [CrossRef] [PubMed]

27. National Food Institute Cereals and Starch Products. Available online: https://frida.fooddata.dk/index.php/food/lists/ grouped/26?lang=en\&\#group26 (accessed on 20 January 2021).

28. INRAE CIRAD AFZ Cereal Byproducts-Tables of Composition and Nutritional Values of Feed Materials. Available online: https: / / feedtables.com/ (accessed on 20 January 2021). 
29. Rizzello, C.G.; Nionelli, L.; Coda, R.; De Angelis, M.; Gobbetti, M. Effect of sourdough fermentation on stabilisation, and chemical and nutritional characteristics of wheat germ. Food Chem. 2010, 119, 1079-1089. [CrossRef]

30. Cardoso, R.V.C.; Fernandes, Â.; Barreira, J.C.M.; Verde, S.C.; Antonio, A.L.; Gonzaléz-paramás, A.M.; Barros, L.; Ferreira, I.C.F.R. Effectiveness of gamma and electron beam irradiation as preserving technologies of fresh Agaricus bisporus Portobello: A comparative study. Food Chem. 2019, 278, 760-766. [CrossRef]

31. Barreira, J.C.M.; Pereira, J.A.; Oliveira, M.B.P.P.; Ferreira, I.C.F.R. Sugars profiles of different chestnut (Castanea sativa Mill.) and almond (Prunus dulcis) cultivars by HPLC-RI. Plant Foods Hum. Nutr. 2010, 65, 38-43. [CrossRef]

32. Abdelghany, A.M.; Zhang, S.; Azam, M.; Shaibu, A.S.; Feng, Y.; Qi, J.; Li, Y.; Tian, Y.; Hong, H.; Li, B.; et al. Natural variation in fatty acid composition of diverse world soybean germplasms grown in China. Agronomy 2020, 10, 24. [CrossRef]

33. Becker, R. Fatty acids in food cereal grains and grain products. In Fatty Acids in Foods and their Health Implications; CRC Press: Boca Raton, FL, USA, 2000.

34. Armanino, C.; De Acutis, R.; Festa, M.R. Wheat lipids to discriminate species, varieties, geographical origins and crop years. Anal Chim. Acta 2002, 454, 315-326. [CrossRef]

35. Nikolić, N.; Radulović, N.; Momcilović, B.; Nikolić, G.; Lazić, M.; Todorovic, Z. Fatty acids composition and rheology properties of wheat and wheat and white or brown rice flour mixture. Eur. Food Res. Technol. 2008, 227, 1543-1548. [CrossRef]

36. Kan, A. Characterization of the Fatty Acid and Mineral Compositions of Selected Cereal Cultivars from Turkey. Rec. Nat. Prod. 2015, 9, 124-134.

37. Thomas, R.; Bhat, R.; Kuang, Y. Composition of amino acids, fatty acids, minerals and dietary fiber in some of the local and import rice varieties of Malaysia. Int. Food Res. J. 2015, 22, 1148-1155.

38. Górnaś, P.; Radenkovs, V.; Pugajeva, I.; Soliven, A.; Needs, P.W.; Kroon, P.A. Varied composition of tocochromanols in different types of bran: Rye, wheat, oat, spelt, buckwheat, corn, and rice. Int. J. Food Prop. 2015, 19, 1757-1764. [CrossRef]

39. Ansolin, M.; Deboni, T.M.; Richter, W.; Ming, C.C.; Gonçalves, L.A.G. Extraction of Wheat Germ Oil with Alcohol Solvents; UNOPAR: Paraná, Brazil, 2015.

40. Van Hung, P. Phenolic compounds of cereals and their antioxidant capacity. Crit. Rev. Food Sci. Nutr. 2016, 56, 25-35. [CrossRef]

41. Călinoiu, L.F.; Vodnar, D.C. Whole grains and phenolic acids: A review on bioactivity, functionality, health benefits and bioavailability. Nutrients 2018, 10, 1615. [CrossRef] [PubMed]

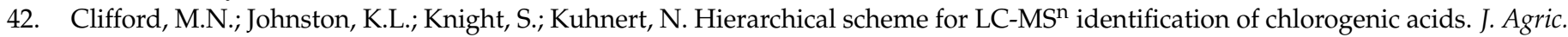
Food Chem. 2003, 51, 2900-2911. [CrossRef] [PubMed]

43. Clifford, M.N.; Knight, S.; Kuhnert, N. Discriminating between the six isomers of dicaffeoylquinic acid by LC-MS ${ }^{\mathrm{n}}$. J. Agric. Food Chem. 2005, 53, 3821-3832. [CrossRef] [PubMed]

44. Ferreres, F.; Gomes, N.G.M.; Valentão, P.; Pereira, D.M.; Gil-Izquierdo, A.; Araújo, L.; Silva, T.C.; Andrade, P.B. Leaves and stem bark from Allophylus africanus P. Beauv.: An approach to anti-inflammatory properties and characterization of their flavonoid profile. Food Chem. Toxicol. 2018, 118, 430-438. [CrossRef]

45. Hirawan, R.; Beta, T. C-Glycosylflavone and lignan diglucoside contents of commercial, regular, and whole-wheat spaghetti. Cereal Chem. J. 2011, 88, 338-343. [CrossRef]

46. Roriz, C.L.; Barros, L.; Carvalho, A.M.; Santos-Buelga, C.; Ferreira, I.C. Pterospartum tridentatum, Gomphrena globosa and Cymbopogon citratus: A phytochemical study focused on antioxidant compounds. Food Res. Int. 2014, 62, 684-693. [CrossRef]

47. Andreasen, M.F.; Christensen, L.P.; Meyer, A.S.; Hansen, Å. Content of phenolic acids and ferulic acid dehydrodimers in 17 rye (Secale cereale L.) varieties. J. Agric. Food Chem. 2000, 48, 2837-2842. [CrossRef]

48. Kulichová, K.; Sokol, J.; Nemeček, P.; Maliarová, M.; Maliar, T.; Havrlentová, M.; Kraic, J. Phenolic compounds and biological activities of rye (Secale cereale L.) grains. Open Chem. 2019, 17, 988-999. [CrossRef]

49. Skrajda-Brdak, M.; Konopka, I.; Tańska, M.; Czaplicki, S. Changes in the content of free phenolic acids and antioxidative capacity of wholemeal bread in relation to cereal species and fermentation type. Eur. Food Res. Technol. 2019, 245, 2247-2256. [CrossRef]

50. Zou, Y.; Yang, M.; Zhang, G.; He, H.; Yang, T. Antioxidant activities and phenolic compositions of wheat germ as affected by the roasting process. J. Am. Oil Chem. Soc. 2015, 92, 1303-1312. [CrossRef]

51. Vaher, M.; Matso, K.; Levandi, T.; Helmja, K.; Kaljurand, M. Phenolic compounds and the antioxidant activity of the bran, flour and whole grain of different wheat varieties. Procedia Chem. 2010, 2, 76-82. [CrossRef]

52. López-Perea, P.; Guzmán-Ortiz, F.A.; Román-Gutiérrez, A.D.; Castro-Rosas, J.; Gómez-Aldapa, C.A.; Rodríguez-Marín, M.L.; Falfán-Cortés, R.N.; González-Olivares, L.G.; Torruco-Uco, J.G. Bioactive compounds and antioxidant activity of wheat bran and barley husk in the extracts with different polarity. Int. J. Food Prop. 2019, 22, 646-658. [CrossRef]

53. Samyor, D.; Deka, S.C.; Das, A.B. Phytochemical and antioxidant profile of pigmented and non-pigmented rice cultivars of Arunachal Pradesh, India. Int. J. Food Prop. 2016, 19, 1104-1114. [CrossRef]

54. Smuda, S.S.; Mohsen, S.M.; Olsen, K.; Aly, M.H. Bioactive compounds and antioxidant activities of some cereal milling byproducts. J. Food Sci. Technol. 2018, 55, 1134-1142. [CrossRef] [PubMed]

55. Korycińska, M.; Czelna, K.; Jaromin, A.; Kozubek, A. Antioxidant activity of rye bran alkylresorcinols and extracts from whole-grain cereal products. Food Chem. 2009, 116, 1013-1018. [CrossRef]

56. Shahidi, F.; Zhong, Y. Measurement of antioxidant activity. J. Funct. Foods 2015, 18, 757-781. [CrossRef]

57. Călinoiu, L.F.; Vodnar, D.C. Thermal processing for the release of phenolic compounds from wheat and oat bran. Biomolecules 2020, 10, 21. [CrossRef] 